\title{
Høydoserate brakyterapi mot residiverende endetarmskreft etter konvensjonell residivbehandling
}

\author{
Etter primærbehandling av endetarmskreft vil 5-10\% av pasientene få lokalt og regionalt residiv. Ved pro- \\ grediering etter residivbehandling med kirurgi og kjemoradiasjon er behandlingsmulighetene sparsomme. \\ Som de første i Norge har vi behandlet to pasienter med progredierende bekkenresidiv av endetarmskreft \\ etter konvensjonell multimodal residivbehandling med høydoserate brakyterapi.
}

I 2010 fikk 3872 nordmenn kolorektal cancer. Av disse var $34 \%$ lokalisert i rectum (1). Innføring av multimodal behandling med samtidig kjemoterapi, ekstern strålebehandling og radikal kirurgi hos pasienter med størst fare for lokal behandlingssvikt, har redusert insidensen av lokalt og regionalt tilbakefall i bekkenet til cirka 5-10\% (2).

Lokale bekkenresidiver av endetarmskreft må alltid vurderes med henblikk på operabilitet. Kirurgi er oftest den optimale behandlingen med akseptabel livskvalitet for pasienten. Komplett kirurgisk eksisjon med eller uten kjemoradiasjon av lokalt residiverende tumorer vil forbedre langtidsprognosen. Men lesjoner som er omgitt av postirradiært arrvev og dyp lokalisasjon i bekkenet, kan vanskeliggjøre kirurgisk intervensjon (3). Hos enkelte pasienter kan man oppnå kurasjon ved behandling av førstegangs residiv, men behandlingen er hos mange pasienter palliativ, da kirurgisk radikalitet kan være vanskelig å oppnå. Pasienter som får annengangs bekkenresidiv er vanligvis ikke kandidater for potensiell kurativ kirurgisk behandling, men bør vurderes for ekstern strålebehandling med palliativt siktemål. Imidlertid har mange pasienter fătt ekstern strålebehandling primært, og samme vevsområde er ofte blitt bestrålt på nytt senere. Et nytt kirurgisk inngrep er da kontraindisert, og fornyet ekstern strålebehandling gir betydelig risiko for toksisitet.

Hovedprinsippet ved all ekstern strålebehandling er å gi høyest mulig dose til et målvolum som omfatter både den maligne tumoren og omkringliggende subklinisk infiltrasjon. Formålet er å oppnå maksimal biologisk respons og god klinisk effekt. Viktigste begrensning for totaldose er stråletoleransen og risiko for toksisitet i bløtvevsstrukturer og i naboorganer rundt tumor. Annengangs ekstern strålebehandling i moderate doser mot residiv av en tidligere bestrålt lokal tumor som residiverer, kan gi god palliasjon med liten risiko for tarmtoksisitet. Fullstendig devitalisering av tumorcellene kan imidlertid ikke forventes. Tredjegangs ekstern strålebehandling kan ikke forventes å gi særlig klinisk effekt, da dosen må begrenses for å unngå alvorlige stråleinduserte bivirkninger.

\section{Høydoserate brakyterapi}

Fokal behandling har i det siste fått økt oppmerksomhet innenfor palliativ kreftbehandling. Høydoserate brakyterapi (HDR-BT: høy stråledose per tidsenhet, braky (gresk: kort): strålebehandling med kort rekkevidde) er en strålebehandlingsteknikk som tillater doseeskalering i et vevsvolum samtidig som naboorganene skånes. Denne metoden har fra 1930-årene og frem til i dag vært et sentralt element i radikal kurativ strålebehandling av gynekologisk kreft på Radiumhospitalet. Pasientene behandles med kombinert ekstern strålebehandling og interstitiell og intrakavitær høydoserate brakyterapi (4). Da strålekildene implanteres direkte inn i tumor, tillater metoden avsetning av stråledoser med høy presisjon og kort rekkevidde, og dosen kan eskaleres opp til et nivå som er biologisk letal for alle tumorceller. I motsetning til ekstern strålebehandling der strålene genereres fra en ekstern kilde, oppnår man redusert risiko for vevsreaksjoner i omkringliggende strålesensitive bløtdelsstrukturer som hud, tarm, blære, genitalia interna og eventuelt prostata - tradisjonelle bivirkninger som ekstern behandling vanligvis påfører pasientene.

I 2004 ble høydoserate brakyterapi innført $i$ behandlingen av prostatakreft i Norge. Til nå er det behandlet ca. 800 prostatakreftpasienter med denne behandlingsformen på Radiumhospitalet, og resultatene etter behandling av de 275 første pasientene er gode både når det gjelder tumorkontroll og bivirkninger (5-7). Etterladningsteknikken som benyttes er meget strålehygienisk, da strålekildene introduseres automatisk inn i hule stålnåler i tumor uten at helsepersonell er til stede (8). Brakyterapi er også tatt i bruk internasjonalt $i$ behandlingen av en rekke andre solide tumorer, som regel i et multimodalt opplegg med kurativ målsetning.

På bakgrunn av vår betydelige erfaring med høydoserate brakyterapi av prostatakreft fant vi grunn til å introdusere metoden $\mathrm{i}$ behandlingen av to pasienter med residiv av endetarmskreft der gode tumorrettede behandlingsmetoder var uttømte. Pasientene hadde ingen komplikasjoner etter høydoserate brakyterapi og senere i sykdomsforløpet, og vi oppnådde komplett remisjon av lokal sykdomsaktivitet både radiologisk og scintigrafisk vurdert med MR- og PETskan hos begge pasienter (fig 1). Dette er i samsvar med resultatene til Kolotas, som av 20 transperineale og 20 transsakrale CTveiledede implantasjoner observerte kun fire pasienter med tumorprogrediering i bestrålt volum (9). Ingen i dette materialet fikk akutte komplikasjoner, men én pasient utviklet en fistel etter åtte måneder. Dette kan være en risiko hvis det oppstår tynntarmsperforasjon under prosedyren. Alle oppnådde minst $90 \%$ smertereduksjon, med en median varighet på fem måneder. Etter 15 måneders oppfølging var $66 \%$ av pasientene døde av fjernmetastaser. I litteraturen beskrives også biokjemisk effekt med fall av karsinoembryonalt antigen (CEA) etter høydoserate brakyterapi (10). Andre rapporterer også om god lokal kontroll og palliasjon der ikke-radikal kirurgi av bekkenresidiver har vært kombinert med høydoserate brakyterapi $(8,11)$. Imidlertid er langtidskomplikasjoner i form av vevsnekrose og induksjon av ny cancer kjent hos langtidsoverlevere etter strålebehandling. Denne risikoen må alltid overveies når strålebehandling tas i bruk på nye indikasjoner (12).

\section{Forutsetninger}

Inoperable, progredierende bekkensvulster infiltrerer ofte inn i bein og i sakrale røtter. Disse pasientene utvikler gjerne sterke smerter og ender opp med tung analgetisk medikasjon eller epiduralkateter. Kjemoterapi og rebestråling kan gi god palliasjon, men ved ny progrediering i bekkenet uten metastatisk sykdom, mener vi høydoserate brakyterapi kan vurderes som et behandlingsalternativ. En forutsetning for å kunne gi behandlingen er at tumor er lokalisert innenfor nålenes rekkevidde. Tumors beliggenhet må ikke være for nær strålesensitive organer eller store karstrukturer. Involvering av bekkenveggen er ingen absolutt kontraindikasjon (13). Pasientene må være i god allmenntilstand, ha stabil eller langsomt voksende sykdom, være kirurgisk inoperable, tolerere anestesi over mange timer og ikke ha blødningstendens. Behandling med høydoserate brakyterapi kan være kurativ. Risikoen for fremtidig mikrometastasering er imidlertid høy, noe som pasienten må orienteres om. 


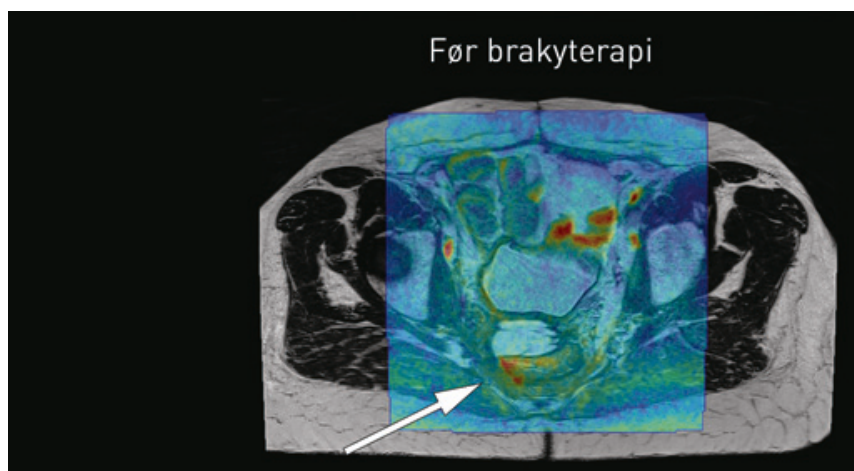

$\mathrm{T} 2 \mathrm{~W}+\mathrm{DWI}$

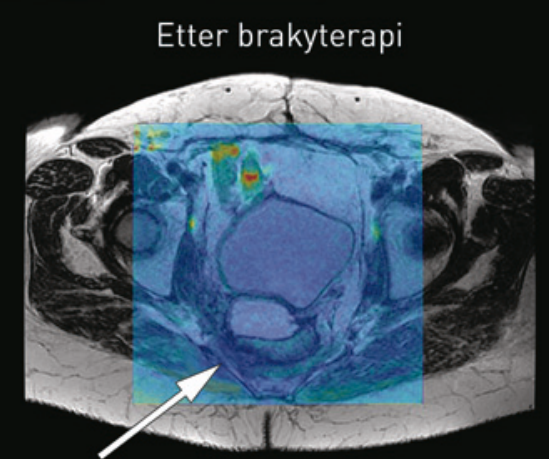

$\mathrm{T} 2 \mathrm{~W}+\mathrm{DWI}$

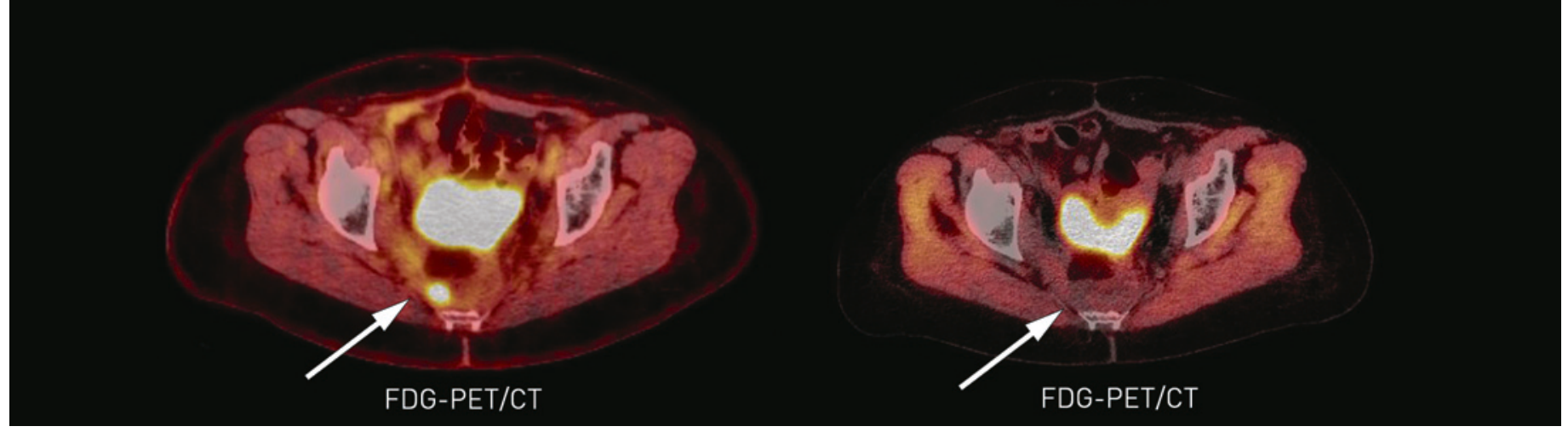

Figur 1 MR- og PET-skann før og ett år etter behandling med høydose brakyterapi hos pasient med solitært residiv av endetarmskreft i bekkenet

Våre erfaringer tyder på at høydoserate brakyterapi er en gjennomførbar og godt tolerabel behandling hos pasienter med endetarmskreft med progrediering i bekkenet. Behandlingen kan være symptomforebyggende, gi god palliasjon og være et godt terapeutisk alternativ hos selekterte pasienter med smertefulle eller truende residiverende tumorlesjoner i bekkenet etter at etablert residivbehandling har sviktet. Med den gode effekten i den behandlede residivtumoren kan man håpe på at denne spesifikke lesjonen ikke gir opphav til nye og plagsomme symptomer.

\section{Nils Kristian Raabe \\ nils.raabe@online.no \\ Kolbein Sundfør \\ Knut Håkon Hole \\ Linda Holth Djupvik \\ Stein Gunnar Larsen \\ Svein Dueland}

Nils Kristian Raabe (f. 1946) er spesialist i onkologi og i indremedisin, dr.med. og overlege. Han er tilknyttet CC-Vest legesenter og har spesialkompetanse innen uroonkologi og høydoserate brakyterapi.

Forfatter har fylt ut ICMJE-skjemaet og oppgir ingen interessekonflikter.

Kolbein Sundfør (f. 1944) er spesialist i fødselshjelp og kvinnesykdommer, dr.med. og overlege ved Oslo universitetssykehus, Radiumhospitalet, med spesialkompetanse innen strålebehandling av gynekologisk kreft.

Forfatter har fylt ut ICMJE-skjemaet og oppgir ingen interessekonflikter.
Knut Håkon Hole (f. 1962) er spesialist i radiologi og overlege ved Oslo universitetssykehus, Radiumhospitalet, med spesialkompetanse innen MR-diagnostikk av kreft.

Forfatter har fylt ut ICMJE-skjemaet og oppgir ingen interessekonflikter.

Linda Holth Djupvik (f. 1977) er sivilingeniør og medisinsk fysiker innen stråleterapi på Avdeling for medisinsk fysikk, Oslo universitetssykehus, Radiumhospitalet.

Forfatter har fylt ut ICMJE-skjemaet og oppgir ingen interessekonflikter.

Stein Gunnar Larsen (f. 1957) er spesialist i gastroenterologisk kirurgi, dr.med. og overlege ved Gastrokirurgisk avdeling, Oslo universitetssykehus, Radiumhospitalet.

Forfatter har fylt ut ICMJE-skjemaet og oppgir ingen interessekonflikter.

Svein Dueland (f. 1954) er spesialist i onkologi, dr. med. og overlege med spesialområde mage-/tarmkreft og utprøvende behandling ved Oslo universitetssykehus.

Forfatter har fylt ut ICMJE-skjemaet og oppgir ingen interessekonflikter.

\section{Litteratur}

1. Kreftregisteret. www.kreftregisteret.no (19.9.2014)

2. Bosset JF, Collette L, Calais G et al. Chemotherapy with preoperative radiotherapy in rectal cancer. N Engl J Med 2006; 355: 1114-23.

3. Moriya Y. Treatment strategy for locally recurrent rectal cancer. Jpn J Clin Oncol 2006; 36: 127-31. 4. Sundfør K, Tropé CG, Kjørstad KE. Radical radiotherapy versus brachytherapy plus surgery in carcinoma of the cervix $2 \mathrm{~A}$ and $2 \mathrm{~B}$-long-term results from a randomized study 1968-1980. Acta Oncol 1996; 35 (suppl 8): 99-107.
5. Raabe NK, Lilleby W, Tafjord G et al. Høydoserate brakyterapi ved prostatakreft i Norge. Tidsskr Nor Legeforen 2008: 128: 1275-8.

6. Lilleby W, Tafjord G, Raabe NK. Implementation of high-dose-rate brachytherapy and androgen deprivation in patients with prostate cancer. Int J Radiat Oncol Biol Phys 2012; 83: 933-9.

7. Raabe NK, Tafjord G, Lilleby W. Høydoserate brakyterapi, ekstern strålebehandling og androgen deprivasjon ved cancer prostatae. Resultater etter behandling av de første 275 pasienter i Norge. Tidsskr Nor Legeforen 2012; 132: 1074. www.tidsskriftet.no/raabeappendiks (19.9.2014).

8. Kuehne J, Kleisli T, Biernacki P et al. Use of highdose-rate brachytherapy in the management of locally recurrent rectal cancer. Dis Colon Rectum 2003; 46: 895-9.

9. Kolotas C, Baltas D, Zamboglou N. CT-Based interstitial HDR brachytherapy. Strahlenther Onko 1999; 175: 419-27.

10. Koutrouvelis PG. Computed tomography-guided salvage brachytherapy of recurrent large nonresectable familial colo-rectal cancer in the pelvis case report. Technol Cancer Res Treat 2002; 1 : $61-4$.

11. Goes RN, Beart RW Jr. Simons AJ et al. Use of brachytherapy in management of locally recurrent rectal cancer. Dis Colon Rectum 1997; 40: 1177-9.

12. Zelefsky MJ, Housman DM, Pei X et al. Incidence of secondary cancer development after high-dose intensity-modulated radiotherapy and imageguided brachytherapy for the treatment of localized prostate cancer. Int J Radiat Oncol Biol Phys 2012; 83: 953-9.

13. Kolotas C. Röddiger S, Strassmann G et al. Palliative interstitial HDR brachytherapy for recurrent rectal cancer. Implantation techniques and results. Strahlenther Onkol 2003; 179: 458-63.

Mottatt 25.2. 2013, første revisjon innsendt 18.11. 2013, godkjent 22.9. 2014. Redaktør: Hanne Støre valeur.

Publisert først på nett. 